(1)

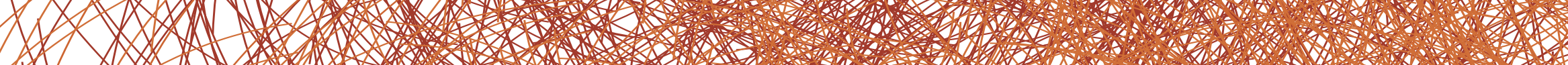
WL W W 12 W 121 .

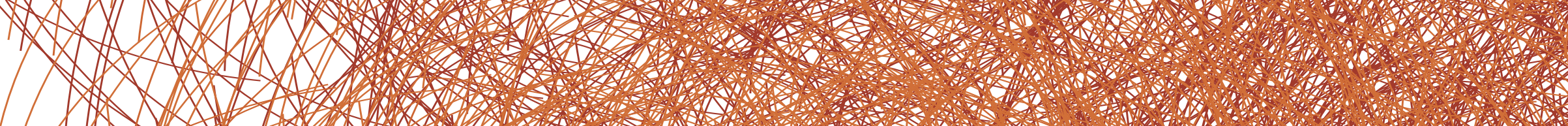

\title{
LES ATELIERS
} DE L'ÉTHIQUE Yot ETE/SUMMER 2009

\section{LA REVUE DU CREUM}

\section{2}

11

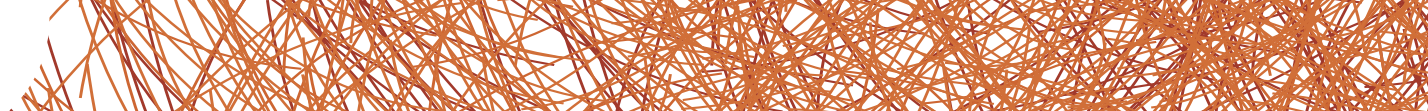

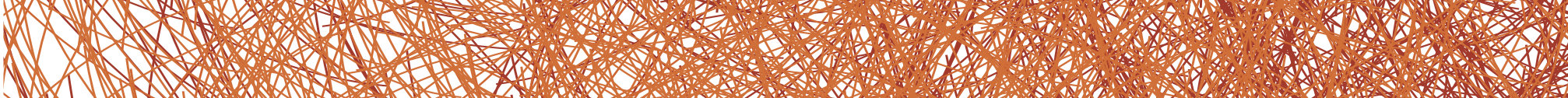
(

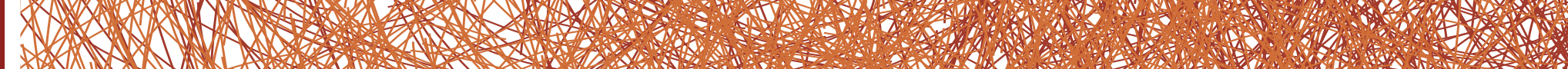
CREUM 


\section{UNE REVUE MULTI- DISCIPLINAIRE SUR LES ENJEUX NORMATIFS DES POLITIQUES PUBLIQUES ET DES PRATIQUES SOCIALES.}

$\eta$

\begin{abstract}
VOLUME 4 NUMÉRO ÉTÉ/SUMMER 2009
\end{abstract}

\section{COMITÉ ÉDITORIAL/EDITORIAL COMMITTEE}

Rédacteur en chef/Editor: Daniel Marc Weinstock, CRÉUM

Coordonnateur de rédaction/Administrative Editor: Martin Blanchard, CRÉUM (martin.blanchard@umontreal.ca)

\section{COMITÉ EXÉCUTIF DE RÉDACTEURS / EXECUTIVE EDITORS}

Éthique fondamentale : Christine Tappolet, CRÉUM Éthique et politique : Daniel Marc Weinstock, CRÉUM

\section{COMITÉ D'EXPERTS / BOARD OF REFEREES:}

Charles Blattberg, CRÉUM

Rabah Bousbaci, CRÉUM

Ryoa Chung, CRÉUM

Francis Dupuis-Déri, Université du Québec à Montréal Geneviève Fuji Johnson, Université Simon Fraser

Axel Gosseries, Université de Louvain-la-Neuve

Béatrice Godard, CRÉUM

\section{NOTE AUX AUTEURS}

Un article doit compter de 10 à 20 pages environ, simple interligne (Times New Roman 12). Les notes doivent être placées en fin de texte. L'article doit inclure un résumé d'au plus 200 mots en français et en anglais. Les articles seront évalués de manière anonyme par deux pairs du comité éditorial.

Les consignes aux auteurs se retrouvent sur le site de la revue (www.creum.umontreal.ca/ateliers). Tout article ne s'y conformant pas sera automatiquement refusé.
Éthique et santé : Bryn Williams-Jones, CRÉUM Éthique et économie : Peter Dietsch, CRÉUM
Joseph Heath, Université de Toronto Mira Johri, CRÉUM

Julie Lavigne, Université du Ouébec à Montréal

Robert Leckey, Université McGill

Christian Nadeau, CRÉUM

Wayne Norman, CRÉUM

Luc Tremblay, CRÉUM

\section{GUIDELINES FOR AUTHORS}

Papers should be between 10 and 20 pages, single spaend of the text. An abstract in English and French of no more than 200 words must be inserted at the beginning of the text. Articles are anonymously peer-reviewed by members of the editorial committee.

Instructions to authors are available on the journal web site (www.creum.umontreal.ca/ateliers). Papers not following these will be automatically rejected. ced (Times New Roman 12). Notes should be placed at the

\section{A MULTIDISCIPLINARY JOURNAL ON THE NORMATIVE CHALLENGES OF PUBLIC POLICIES AND SOCIAL PRACTICES.}

\section{cc)creative

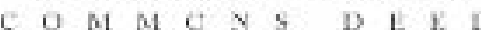

Vous êtes libres de reproduire, distribuer et communiquer les textes de cette revue au public selon les conditions suivantes:

- Vous devez citer le nom de l'auteur et de la revue

- Vous ne pouvez pas utiliser les textes à des fins commerciales - Vous ne pouvez pas modifier, transformer ou adapter les textes

Pour tous les détails, veuillez vous référer à l'adresse suivante http://creativecommons.org/licenses/by-nc-nd/2.5/legalcode
You are free to copy and distribute all texts of this journal under the following conditions:

- You must cite the author of the text and the name of the journal - You may not use this work for commercial purposes - You may not alter, transform, or build upon this work

For all details please refer to the following address: http://creativecommons.org/licenses/by-nc-nd/2.5/legalcode 


\section{DOSSIER LE NÉO-RÉPUBLICANISME}

16-24 INTRODUCTION .Alice Le Goff et Dave Anctil

25-42 LE CARE ENTRE DÉPENDANCE ET DOMINATION : L’INTERÊT DE LA THÉORIE

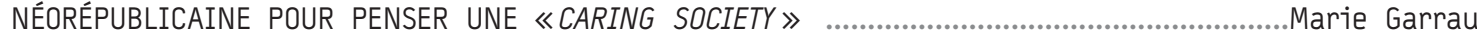

43-54 LE MULTICULTURALISME, UN PROJET RÉPUBLICAIN ? ........................................Sophie Guérard de Latour

55-64 PRÉFÉRENCES DÉCISIVES ET PRÉCARITÉ Vincent Bourdeau

\section{TABLE DES MATIÈRES}

65-80 LA LIBERTÉ RÉPUBLICAINE ET LA DÉMOCRATISATION DU RÉGIME INTERNATIONAL ...Dave Anctil

81-101 LA RECONNAISSANCE ENTRE ÉCHANGE, POUVOIRS ET INSTITUTIONS

LE RÉPUBLICANISME DE PHILIP PETTIT

Christian Lazzer

102-110 RÉPUBLICANISME ET DISTRIBUTION DE L’ESTIME SOCIALE: LECTURES CROISÉES

..Alice Le Goff

111-129 ENTRETIENS AVEC CÉCILE LABORDE

Alice Le Goff et Dave Anctil

DOSSIER SUR LA NEUTRALITÉ LIBÉRALE / ON LIBERAL NEUTRALITY

130-133 INTRODUCTION Roberto Merrill et Geneviève Rousselière

\section{VOLUME 4 NUMÉRO ETÉ/SUMMER 2009}

\section{TABLE OF CONTENTS}

134-150 NEUTRALITY AND THE SOCIAL CONTRACT Ian J. Carroll

151-158 LIBERAL NEUTRALITY: CONSTRUCTIVIST, NOT FOUNDATIONALIST 159-174 NEUTRALITY AS A TWOFOLD CONCEPT .Alexa Zellentin 175-186 TOLÉRANCE ET NEUTRALITÉ: INCOMPATIBLES OU COMPLÉMENTAIRES? .Marc Rüegger 187-201 AN EPISTEMIC ARGUMENT IN SUPPORT OF LIBERAL NEUTRALITY Mariano Garreta Leclercq 202-213 ARE CITIES ILLIBERAL? MUNICIPAL JURISDICTIONS AND THE SCOPE OF LIBERAL NEUTRALITY Patrick Turmel

214-225 PERFECTIONISM, ECONOMIC (DIS)INCENTIVES, AND POLITICAL COERCION ...ran Moked 226-235 BEYOND EQUALITY OF WHAT: SEN AND NEUTRALITY .Christopher Robert Lowry 


\section{ABSTRACT:}

Based on a close reading of the debate between Rawls and Sen on primary goods versus capabilities, I argue that liberal theory cannot adequately respond to Sen's critique within a conventionally neutralist framework. In support of the capability approach, I explain why and how it defends a more robust conception of opportunity and freedom, along with public debate on substantive questions about well-being and the good life. My aims are: (i) to show that Sen's capability approach is at odds with Rawls's political liberal version of neutrality; (ii) to carve out a third space in the neutrality debate; and (iii) to begin to develop, from Sen's approach, the idea of public value liberalism as a position that falls within that third space.

\section{RÉSUMÉ :}

\section{VOLUME 4 NUMÉRO 2

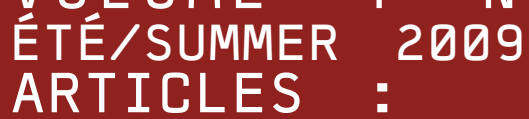

BEYOND EQUALITY OF WHAT: SEN AND NEUTRALITY*

\author{
CHRISTOPHER ROBERT LOWRY* * \\ THE CHINESE UNIVERSITY OF HONG KONG
}

En me basant sur une lecture attentive du débat entre Rawls et Sen sur les biens premiers versus les capabilités, je soutiendrai que la théorie libérale est incapable, dans un cadre neutraliste conventionnel, de répondre adéquatement à des injustices dans le domaine de la santé. À partir de l'approche des capabilités, j'explique pourquoi et comment cette approche permet de défendre une conception plus robuste de l'opportunité et de la liberté, de même qu'un débat public sur des questions substantielles concernant le bien-être et la vie bonne. Mes objectifs sont : (i) de clarifier le rapport entre le neutralisme de Rawls et sa défense des biens premiers, (ii), de démontrer les implications de la critique des capabilités de Sen, et (iii), d'esquisser une troisième position dans le débat sur la neutralité versus le perfectionnisme - à savoir, celle d'un perfectionnisme motivé par des considérations de légitimité. 
The influence of Amartya Sen's capability approach extends across a number of academic disciplines and political contexts. ${ }^{1}$ Within political philosophy, the capability approach ${ }^{2}$ is principally regarded as an important contribution to the metric of advantage debate, alongside such other metrics as Rawls's social primary goods, Dworkin's resources, Cohen's access to advantage, and Arneson's opportunity for welfare, among others. ${ }^{3}$ This paper demonstrates that Sen's arguments and position also bear on the liberal debate about neutrality versus perfectionism. ${ }^{4}$ Sen himself has shied away from entering into this second debate. ${ }^{5}$ This is unfortunate. Once his view's implications for liberal neutrality are spelled out, the capability approach yields a distinctive alternative in-between the standard versions of neutrality and perfectionism, which I will refer to as 'public value perfectionism'. I have three aims in this paper: (i) to show that Sen's capability approach is at odds with Rawls's political liberal version of neutrality; (ii) to carve out a third space in the neutrality debate; and (iii) to begin to develop, from Sen's approach, the idea of public value liberalism as a position that falls within that third space.

The first of these tasks involves explaining how the move to capability is not only a move away from primary goods, it is also a move away from Rawls's account of liberal neutrality. ${ }^{6}$ I identify three interrelated features of Sen's approach that are at odds with Rawls's neutralism. First, Sen rejects Rawls's idea of a strictly political conception of autonomy. Second, Sen shows little interest in confining himself to reasons, ideas and values that are political in the Rawlsian sense. ${ }^{7}$ Third, Sen's view does not confine our collective evaluation of the good life to the social domain of civil society.

To tackle the second task, I argue that the neutrality debate deals not only with the question of whether substantial evaluation of the good has a place in the political domain, but also with the question of whether political philosophy should have an aspirational commitment, as opposed to confining its attention to conditions of legitimacy. The neutrality debate thus has a legitimation-aspiration dimension as well as a neutrality-perfectionism dimension-with legitimation typically joined to neutrality, and aspiration to perfectionism. However, there is no incoherence in the idea of perfectionism motivated by legitimation.

The third task involves arguing that "perfectionism for legitimation' is an apt description of the position - which I call 'public value perfectionism' - that can be developed from Sen's capability approach.
I defend that characterization by identifying the legitimacy-oriented reasons for rejecting primary goods in favour of a metric that seeks to address human difference, including illness and disability.

The paper proceeds in four sections. I begin with a discussion of the neutrality versus perfectionism debate and Sen's comments thereupon. Next I explain Sen's objection to primary goods and its connection to the question of state legitimacy. In the third section, I explain why and how Sen's capability approach gives importance to the public evaluation of the value of activities and states of being. The final section contains my defence of the claim that Sen's capability approach puts him at odds with Rawls's political liberal version of neutralism, and of the claim that Sen's view provides a basis for defending public value perfectionism as a distinctive third position in the neutrality versus perfectionism debate.

\section{NEUTRALITY VERSUS PERFECTIONISM}

Liberal neutrality is a position about what makes the authority of the state legitimate. The legitimacy question is a vexing one for liberals because they defend the claim that "political power is always coercive power" together with a view of the person that gives pride of place to individual freedom. ${ }^{8}$ The task, then, is to provide a justification of the social and institutional arrangements shaped (or shapeable) by the state's power that all members of society can defensibly be expected to be able to reconcile with their freedom and equality as citizens. Liberal neutralists claim that when a society contains a diversity of world views that respect the rights of others, any defensible justification of state authority must be a neutral one that does not appeal to claims about the intrinsic superiority of any particular conception of the good. ${ }^{9}$

State perfectionism comes in many forms, not all of them liberal. ${ }^{10}$ What they share in common is the defence of at least some degree of objectivity about value paired with the claim that the state should play a role in the promotion of objective value. What we might call 'Nietzschean perfectionism' would pursue that goal by funneling social resources into the production of a few extraordinary specimens of humanity. Communitarian perfectionism instructs the state to promote a single shared common way of life. In liberal versions, perfectionist goals are tempered by recognition of the value of cultural pluralism (contra communitarianism) and a commitment to egalitarianism (contra Nietzsche). ${ }^{11}$ This paper is concerned only with the third group. 
Liberal perfectionists defend state actions that are justified by an appeal to a limited objective conception of well-being (limited in the sense that it by no means encompasses all aspects of life); and they do so for egalitarian reasons ${ }^{12}$ and in a way that aims to give due weight to the importance of citizens having the freedom and opportunity to pursue a plurality of conceptions of the good. Note that perfectionism so described is, like neutralism, a position about the justification of state actions. ${ }^{13}$

Some alternative descriptions of the debate characterize perfectionism as any view defending state activities that promote-by intention or in effect-particular ways of life over others. ${ }^{14}$ I find such descriptions unhelpful. Neutralist liberalism favors ways of life that do not violate the rights of others, that are conducive to a public ethos of civility, and that support the survival and strengthening of liberal democratic norms; and neutralists defend the state promotion of such ways of life on the basis of neutral justifications. ${ }^{15}$ The anti-perfectionism of liberal neutrality is best located at the level of state justification.

The focus on justification, however, tends to underemphasize another feature of the positions - namely, that perfectionist theories typically have an aspirational quality, which is often absent in neutralist theories. Liberal perfectionism is typically motivated by a progressive politics that is concerned to advance the well-being or human flourishing of all citizens, particularly those whose access to valuable activities is hampered by economic disadvantage.$^{16}$ This ambitious view of the purpose and scope of state authority depends on at least two claims: (i) liberal democratic norms can be justified in terms of well-being contribution, and (ii) the project of well-being promotion can successfully include an active leadership role for the state. Rawls's political liberal version of neutralism rejects both of those claims, and adopts instead the more modest goal of defending the core features of liberal institutions as a fair basis for legitimating the authority of the state. ${ }^{17}$ In other words, political liberalism argues that the state should do what it must do to be legitimate; whereas the standard versions of perfectionism go further to argue that the state should also do whatever it can do to promote well-being - a goal deemed pursuable in part because of perfectionist theories' typically less demanding standards of legitimacy.

The links between perfectionism and aspiration and between neutrality and legitimation are quite strong in the literature, but they are not conceptually necessary. The third position that I will begin to devel- op from Sen's capability approach can be described as perfectionism motivated by legitimation. That position, which I call public value perfectionism, is motivated by two thoughts concerning certain conditions of legitimacy (specified in Section III below) that relate to the fair distribution of advantage: (i) that Rawls's neutralist liberalism is unable to satisfy those conditions in a way that adequately takes into account human difference, including illness and disability; and (ii) that overcoming this limitation requires some public, political engagement with questions about perfectionist value - more specifically, questions about which 'doings' and 'beings' are valuable.

Turning now to Sen's comments on the neutrality debate, he has directly referred to the issue of state neutrality twice in his writings, both times in a footnote. Those two comments should first be addressed, in order to cut off the objection that the question of capability and neutrality was resolved - in favour of neutralism - nearly twenty years ago in "Justice: Means versus Freedoms". ${ }^{18}$ In that article, Sen argues that Rawls was mistaken when he claimed that capability comparisons require a prior specification of one particular comprehensive view of the good. ${ }^{19}$ Sen responds,

$$
\begin{aligned}
& \text { Capability reflects a person's freedom to choose between alterna- } \\
& \text { tive lives (functioning combinations), and its value need not be } \\
& \text { derived from one particular "comprehensive doctrine" demanding } \\
& \text { one specific way of living. }{ }^{20}
\end{aligned}
$$

This passage shows that Sen is not a communitarian perfectionist, but we cannot therefore infer that he is neutralist. Similarly, Sen's agreement with Rawls that people should not be compensated for their choices of ends (their so-called 'inter-end variation') does not demonstrate a commitment to neutrality, because holding people responsible for the effects of their choices is also compatible with liberal perfectionism. ${ }^{21}$

In the first of his two notes on neutrality, Sen recognizes neutrality ${ }^{22}$ as important, especially for Rawls's theory.

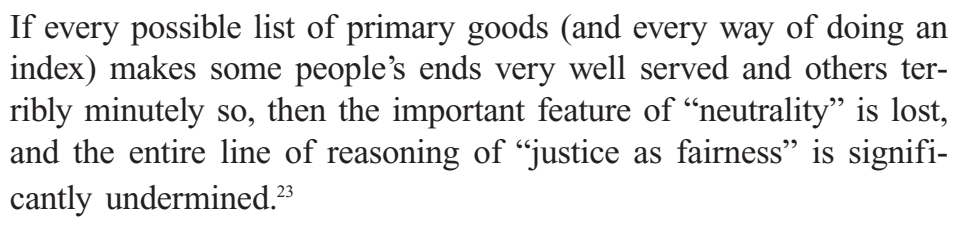

However, this passage is not a direct endorsement of neutrality. Moreover, Sen's second note, which is made in the context of 
Inequality Reexamined's critical discussion of Rawls's political conception of justice, expresses ambivalence toward the neutralist project.

There is a relate-but larger-issue regarding the exact role of 'neutrality' in political liberalism and the feasibility and desirability of imposing neutrality on theories of justice and fairness. ... The discussion here bears on that issue, but I shall not, here, go on to a fuller treatment of that larger problem. ${ }^{24}$

This shows that the question of capability and neutrality is a live one The fuller treatment towards which Sen gestured has not yet surfaced; this paper's fourth section will take on that task.

\section{SEN'S OBJECTION TO PRIMARY GOODS}

As preparation for discussion of the capability approach and its relevance for the neutrality versus perfectionism debate, this section explains Sen's objection to primary goods and its bearing on the question of state legitimacy. Sen argues that Rawls mistakes primary goods for what is valuable, making him guilty of 'goods fetishism'. ${ }^{25}$ In Sen's view, what is valuable is the power that primary goods give people to pursue their objectives. He accuses Rawls of focusing only on the 'means to freedom', when what matters is the 'extent of freeARTICLES dom'. ${ }^{26}$

I do not think Sen's objection is best phrased in terms of charging Rawls with goods fetishism or with valuing only the means to freedom, even though this is, in fact, the phrasing Sen chooses. What he should have said is that Rawls mistakenly defends primary goods as an adequate indicator of positive freedom. Consider the following passage from Rawls:

[T] he worth, that is, the usefulness of [the basic] liberties ... is estimated by the index of primary goods... The difference principle, in maximizing the index available to the least advantaged, maximizes the worth to them of the equal liberties enjoyed by all Yet some have more income and wealth than others, and so more all-purpose means for realizing their ends. ${ }^{27}$

The basic liberties have worth for an individual to the extent that she can make use of them to pursue her ends. A person's share of primary goods estimates this worth. Therefore, primary goods are meant to tell us how well a person can make use of her liberties in pursuit of her ends - in other words, how much power she has to pursue her ends.

Sen's objection should be understood not as accusing Rawls of denying that positive freedom is what matters, but rather as rejecting the adequacy of primary goods as an indicator of positive freedom. The objection is based on the importance of what Sen calls 'interindividual variation'. This refers to differences in what I will call 'conversion ability', which Sen describes as "what power [a person] has to convert primary goods into the fulfillment of [her] ends." 28 Rawls rules out differences in conversion ability. He argues that for the purpose of formulating the fundamental principles of a theory of justice, it is appropriate to adopt a simplifying assumption that takes all citizens to be "normal and fully cooperating members of society." ${ }^{29} \mathrm{He}$ writes,

[W]e have made an important background assumption: namely, that with respect to the kinds of needs and requirements that political justice should take into account, citizens' needs and requirements are sufficiently similar for an index of primary goods to serve as a suitable and fair basis for interpersonal comparisons in matters of political justice. ${ }^{30}$

According to this assumption, a given share of primary goods increases positive freedom in roughly the same way for everyone. Inter-individual variation is disregarded.

Sen rejects Rawls's simplifying assumption for several reasons. First, differences in conversion ability do not merely constitute exceptional cases. These differences are pervasive, applying to all sectors of humanity. ${ }^{31}$ To make this claim plausible, Sen points to numerous sources of variation, including: "age, sex, physical and mental health, bodily prowess, intellectual abilities, climatic circumstances, epidemiological vulnerability, [and] social surroundings." ${ }^{\prime 32}$ Second, Sen claims that these differences are significant in their effects: "[o]ur physical and social characteristics make us immensely diverse creatures.", ${ }^{33}$ Finally, and most importantly, these differences are to a large extent morally arbitrary ${ }^{34}$ in much the same way as the natural and social contingencies to which Rawls famously draws our attention. ${ }^{35}$ The claim then is that differences in conversion ability are pervasive, profound and morally arbitrary. To further strengthen Sen's argument, I will now explain how these points relate to state legitimacy, which requires returning briefly to Rawls. 
The morally arbitrary natural and social contingencies that Rawls addresses affect a person's economic talent-her ability to convince others to offer high rewards for her labour power. Rawls therefore argues that in the case of economic rewards, appeals to moral desert are unwarranted; and yet he nonetheless defends an economic system with differential rewards that favour those whose contributions are more valued by others. In Rawls's view, the moral arbitrariness of talent does not give us cause to reject the practice of giving higher pay to those who work harder or better; rather, it gives us reason to implement a tax and transfer system that adjusts the levels of advantage attached to the various social positions so that the occupants of the least advantaged position benefit in absolute terms from the inequalities of the cooperative scheme. This framework specifies how individuals can take advantage of their place in the distribution of talent in a way that they can reasonably expect those least favoured by that distribution to be able to reasonably accept.

Rawls's theory thus yields a hierarchy of social positions and it affirms the appropriateness of the differential levels of advantage that are attached to them. That is, the theory in effect defends the claim that it is just that social position $\mathrm{P}$ comes with level of advantage $\mathrm{A}$, that position $\mathrm{Q}$ comes with level $\mathrm{B}$, and so on. Note, however, that that claim is not equivalent to the claim that it is just that a particular position comes with a particular share of primary goods. Primary goods are meant to serve as proxy for positive freedom; and, as I argued at the beginning of this section, Rawls and Sen agree that advantage is ultimately a matter of positive freedom. Hence, the fundamental claim about differential advantage is that it is just that a particular position comes with a particular level of positive freedom. The defensibility of substituting primary goods for positive freedom is a further claim. In order to legitimate the state imposition of Rawls's version of the basic structure, both the fundamental claim and the claim about primary goods must be defended as things that all members of society can reasonably be expected to be able to reconcile with their freedom and equality as citizens.

Rawls's arguments in favour of the fundamental claim are quite strong. Since my disagreement is focused elsewhere, I will treat those arguments as fully convincing for the present purposes. The further claim about primary goods, however, is undercut by Sen's objection. An ideal of citizenship that rules out differences in conversion ability is overly exclusive given the epidemiology of human difference. ${ }^{36}$
Once we assume a citizenry that exhibits such difference, it is no longer reasonable to expect that citizens who affirm the fundamental claim - that it is just that a particular social position comes with a particular level of positive freedom - would also be able to reasonably accept the reformulation that replaces positive freedom with primary goods. This is because under the reformulation, the entitlements attached to a particular social position would yield considerably different levels of positive freedom, depending on the morally arbitrary distribution of conversion ability among the occupants of that position. This differential reward conflicts with the fundamental claim.

Rawls defends primary goods out of a desire to measure advantage without measuring positive freedom. But this strategy restricts the reach of egalitarian distributive justice to citizens with physical and mental abilities (and health states) within the normal range. If state authority is to be legitimated, then the basic structure (and its distributive effects) must be reconcilable with the freedom and equality of all citizens, regardless of conversion ability. Seeking a solution to the problems with primary goods is therefore a part of the task of legitimation.

We might be tempted to argue that the problems at hand would be dealt with by the difference principle, since the purpose of that principle is to mitigate the effects of natural lottery. However, the difference principle is designed to address disadvantage between social positions, not within them. Citizens with low conversion ability do not form a distinct social position, because there is no necessary correspondence between conversion ability and economic talent. In the case of conversion ability, any mitigating effect produced by the difference principle would be accidental. Legitimacy considerations give us reason, then, to develop an adequate metric of advantage. Such a metric is achievable, Sen argues, if we measure positive freedom more directly, using the notion of capability.

\section{SEN'S CAPABILITY APPROACH}

This section explains why and how Sen's capability approach gives importance to the public evaluation of the value of activities and states of being. Sen describes capability as 'well-being freedom', the freedom to achieve well-being. He has in mind a robust conception of freedom that includes the presence of social and personal resources. Capability can equally be thought of as a measure of real opportunity, and I find this more intuitive. ${ }^{37}$ Sen's proposal, then, is that we 
measure a person's positive freedom in terms of the real opportunity she has to achieve well-being. In his approach, a person's wellbeing is measured by judging the value of her 'functionings', which are described as 'doings' and 'beings'. A functioning is anything that persons can do or be. The category of doings includes general activities like moving about or communicating with others, as well as very specific activities like chewing spearmint gum or going to see Rent on Broadway.

Note that this inclusiveness extends to both worthwhile and trivial things. The notion of functionings is not inherently evaluative. Consequently, a person's well-being cannot be measured simply by listing her functionings. The value of those functionings must also be judged. The worthwhile activities and states of being that enrich a person's life must be distinguished from her trivial doings and beings that make no contribution to her well-being. A good life is a life where there is value in what a person manages to do and to be. As a description of capability, we can therefore replace "the freedom to achieve well-being" with "the genuine opportunity to engage in valuable activities and achieve valuable states of being." A person has a high level of positive freedom when a wide range of valuable activities and valuable states of being are live options for her. ${ }^{38}$ Sen refers to such a range as a 'capability set'. How, then, do we compare the value of different capability sets?

Sen rejects the count method-which evaluates capability sets according to the number of options in each set - on the grounds that there is an obvious and compelling sense in which a person is given more positive freedom by a set of options she judges to be valuable than by a set of the same number of options she judges to be worthless or detrimental. ${ }^{39}$ Sen argues that the evaluation of capability sets requires judging the value of the options themselves. ${ }^{40}$ We need to come up with a list of which functionings are valuable, and then we have to rank the members of the list in terms of how much value they each have. This bears resemblance to what Griffin calls an objective-list account of well-being, which is not surprising since Sen is significantly objectivist about well-being. ${ }^{41} \mathrm{He}$ writes that "the "limits' of objectivity extend well into the assessment of well-being.".42 However, he does not defend a universal ranking of valuable functionings. In fact, in his theory the evaluation of functionings is done ultimately by individuals. He argues that objectivism about well-being is compatible with giving centrality to individual evaluations, because even with objectivism, it is not unreasonable for different people to evaluate functionings differently. He claims this because (i) he defends a conception of objectivity that is 'position-dependent', and (ii) he expects the value ranking of functionings to be incomplete. ${ }^{43}$ Consequently, when measuring one person's capability, the value of her range of feasible functionings options is to be judged in light of her own 'valuation function' - that is, in light of her own beliefs about the value of functionings.

Of course, as a metric of advantage, the capability approach is primarily meant to be used in society-wide applications, rather than to measure people's individual levels of positive freedom. Sen's rejection of a universal objective ranking of the value of functionings (i.e., a universal valuation function) presents a significant challenge in this regard - especially because he also argues against the feasibility of "inter-valuation-functional" comparisons of well-being. ${ }^{44}$ Comparing different people's well-being requires not only listing and comparing their doings and beings; it also requires attaching values to those functionings. As a result, interpersonal comparisons of either wellbeing or capability require (at least partial) agreement among the relevant people's beliefs about the value of doings and beings. The social evaluation of capability is possible only insofar as a common society-wide valuation function can be established - that is, a public ranking of the value of specified activities and states of being. ${ }^{45}$ Defending capability as our metric of advantage involves defending the need for a public ranking of valuable functionings that is defensibly applicable to all citizens.

A public valuation function makes it possible to judge how much disadvantage is imposed by various factors affecting conversion ability. Using the standard kinds of empirical data familiar to economists, we can check whether there are any consistent discrepancies in the achievement of the particular functionings on the public list. If any such discrepancies can be reliably traced to particular unchosen personal or environmental features, then it can be inferred that those features typically produce conversion impairments. These impairments are differences in conversion ability that reduce the level of positive freedom that a person gets from a particular share of primary goods. To fulfill the requirements of the fundamental claim discussed above (namely, that each social position justly comes with a particular level of positive freedom, which should be sufficiently similar for all occupants of that position), we must seek to determine how best to mit- 
igate or remove the identified conversion impairments. The design of the basic structure must contain an institutional commitment to those goals if that structure is to be something that it is reasonable to expect citizens of varying conversion ability to reasonably accept. The incorporation of that commitment is thus a condition for the legitimacy of liberal state authority.

Typically, what causes unchosen personal features to yield conversion impairments is not only (and sometimes not at all) the nature of those features. A large (and sometimes overwhelming) causal role is played by the social response to those features, which includes how much or how little the features are taken into account in the collective design of our physical and social environments. ${ }^{46}$ We should expect therefore that mitigating or removing conversion impairments will involve a combination of extra resources, physical and institutional accommodations, and, importantly, state support for efforts to revise social environments in the direction of greater inclusion.

\section{CAPABILITY AND PUBLIC VALUE PERFECTIONISM}

Rawls's defense of the doctrine of primary goods as a neutral 'political' conception of the good runs as follows. Since reasonable comprehensive doctrines do not agree on a full conception of the person, we need a political conception of the person as citizen that is built up only from the implications of viewing society as a fair system of social cooperation. This political conception of the citizen makes room for agreement on the needs of people as citizens, from which the list of primary goods, Rawls argues, can be drawn forth.

Sen's view is at odds with Rawls's political liberal version of neutralism in at least three ways that I will presently identify; yet neither does the capability approach fit the mold of the standard versions of liberal perfectionism, as I will explain below. Instead, the capability approach can be argued to yield a third distinctive position in this debate - public value perfectionism. This position is compatible with the neutralist anxiety about aspirational perfectionism, even while it argues against the adequacy of neutralist justice. The result is a defence of a limited role for public evaluation of the good in the political sphere justified by the needs of legitimation. The first two features of Sen's view that I will discuss in this section conflict specifically with the political liberal character of Rawls's neutralism, and they have to do with how Sen envisions the development of a public ranking of valuable functionings.
First, he appeals to the "constructive role" of democracy in the formation of values ${ }^{47} \mathrm{He}$ applauds how the practice of democratic institutions fosters "reasoned scrutiny" of one's inherited views, and he specifies that beliefs about value are politically important only if they can survive reasoned scrutiny. ${ }^{48}$ This suggests a conception of individual autonomy that is more robust than the political liberal version that Rawls defends. Although Sen does not go so far as to defend Mill's ideal of individuality, where actively questioning one's inherited views is regarded as a key component of the good life, Sen's position does nonetheless seem to demand - or at least permit and praisethe state promotion of reasoned scrutiny.

This goes against Rawls's response to reasonable private communitarians - individuals who belong to the overlapping consensus via their permissible conception of the good, yet regard their own comprehensive doctrine as "already formed and firmly held, and in this sense given." 49 Of course, there is no indication that Sen's view demands the coercive imposition of liberal norms in private life, but Rawls insists furthermore that neither should the state non-coercively promote liberal norms in the private lives of the "many persons [who] may not examine their acquired beliefs and ends but take them on faith, or be satisfied that they are matters of custom or tradition. ${ }^{\prime 50}$ Sen's arguments imply that it is important for the state to non-coercively encourage a liberal stance of rational revisability towards one's inherited views. ${ }^{51}$ The broadening and strengthening of social practices of reasoned scrutiny is claimed to play a key role in facilitating overlap among people's beliefs about value, upon which a public ranking of functionings can be based.

Second, the content of that overlapping agreement in Sen's view is at odds with Rawls's political liberalism. In Rawls's view, a defensible conception of justice must not only be able to be the site of an overlapping consensus, it must also be justifiable on the basis of 'political values'. Rawls introduces the idea of the overlapping consensus as a response to worries that the strictly political (in the Rawlsian sense) justification of justice as fairness could not carry sufficient psychological force to earn society-wide allegiance. He concedes this point, but argues that justice as fairness - in its political liberal reformulation - can also be affirmed from within the many different reasonable comprehensive doctrines for non-political reasons peculiar to each, cementing citizens' support for it. The strictly political justification, however, must be provided alongside such affirma- 
tion. Otherwise, political liberalism would be "political in the wrong way.",52

Sen objects to making the provision of strictly political justifications an absolute requirement for a theory of justice. He is rightly concerned that the constraints of political liberalism leave Rawls's theory little power to address the full range of injustices in societies that lack endorsement of the Rawlsian idea of society or that lack political norms of tolerance and public reason. ${ }^{53}$ (I argue in the next section that the constraints of political liberalism also restrict the ability to address particular injustices within liberal democracies associated with conversion impairments.) In Sen's approach, there is no indication that the overlapping agreement on valuational rankings must be based (or be able to be based) on ideas and values that are political in the Rawlsian sense.

The third non-neutralist feature of Sen's view is arguably at odds with political and comprehensive liberal neutralists alike. ${ }^{54}$ Of the three features I discuss, it is the most central to the capability approach as a whole. This feature is the fact that the evaluations of doings and beings required for the creation of the public list unavoidably take place in the public political sphere (as well as in civil society and private life). Sen endorses public debate about values as part of the democratic promotion of reasoned scrutiny, which in turn is important for the feasibility of a public valuation function. ${ }^{55}$ Statements about the value of doings and beings are central to world views. Identifying which activities and states of being are valuable makes up a large part of most full conceptions of the good. Of course, it is not the mere fact that non-political ideas of the good are voiced and discussed in public debate that puts Sen's view at odds with neutralism. In Rawls's 'wide view of public reason', it is appropriate for non-political ideas of the good to be voiced in public political debates so long those ideas are buttressed by political arguments supporting the proposal in question in due course. ${ }^{56}$ Rawls endorses the voicing of non-political values in the public sphere on the grounds that doing so can facilitate mutual understanding between groups with very different perspectives. However, political arguments are to be given principal weight in the discussion and ensuing decisions. Sen's view does not contain this political liberal requirement. His emphasis on reasoned agreement through public debate leaves open the possibility of non-political ideas of the good playing a role-perhaps even a large role - in the creation of a public valuation function. In the next sec- tion I argue furthermore that such a role is inevitable if we are to extend the scope of justice to all citizens regardless of conversion ability. Creating the public list, which is itself a partial conception of the good, thus involves debate in the public political sphere on questions about the good that neutralists argue should be contained within civil society and private life.

On the justification-centered understanding of the neutrality versus perfectionism debate, the fact that Sen's view is at odds with neutralism suggests that his view is therefore committed to a form of perfectionism. That understanding of the debate, however, misses the legitimation-aspiration dynamic between neutralism and perfectionism as each is standardly articulated in the literature. Perfectionist theories typically defend a state duty to encourage citizens to come to value and pursue objectively worthwhile ways of living. Aspirational projects of this kind are not ruled out by the move to measure advantage (conceived of as positive freedom) in terms of capability. But neither do the features of Sen's view commit him to aspirationalism. What Sen's arguments do commit him to is public value perfectionism. This position (in-between neutrality and aspirational perfectionism) defends a limited role for the public deliberation about the good life within state forums, the results of which-if successful-are to be used by the state to ensure fair terms of cooperation for citizens with varying conversion ability, thereby fulfilling a condition for liberal state legitimacy.

\section{CONCLUSION}

To address injustices relating to differences in conversion ability (including illness and disability), what is ultimately required is a specification of the activities and states of being that people reasonably want to be live options for them. Public deliberation about the good is an unavoidable element in the construction of such a list. This demands revising our understanding of the neutrality versus perfectionism debate. I have argued that Sen's capability approach yields a distinctive third position: public value perfectionism. Defending public value perfectionism involves defending the feasibility of a public political exercise that is at odds with neutralism. Creating a public valuation function presents a formidable challenge in light of the multiple diversities of modern liberal democracies - one that must be faced if liberal theory is to affirm the full citizenship of all members of society regardless of conversion ability. 


\section{NOTES}

* Since writing this paper, my position and arguments have undergone several revisions that I have not been able to incorporate into this piece. In particular, I no longer think that merely demonstrating the need for a public ranking of valuable functionings shows that Sen's critique provides the basis for a defence of public value perfectionism. Nonetheless, I hope that the arguments in this paper are of interest. For a fuller account, please see Christopher Lowry, "Perfectionism within Neutrality: Extending Liberal Justice to Citizens with Disabilities", PhD diss. Queen's University, Kingston, Canada, 2009.

** For helpful comments on earlier drafts I am especially indebted to Christine Sypnowich and Will Kymlicka. I would also like to thank Jerome Bickenbach, Amanda Gibeault, Rahul Kumar, Henry Laycock, Andrew Lister, Alistair Macleod, Jim Molos, Margaret Moore, Doug Paletta, Geneviève Rousselière, Jenny Szende, Steven Wall, two anonymous reviewers for this journal, and participants at the International Conference on Liberal Neutratliy organized by the Centre de Recherche en Ethique de l'Université de Montréal, at Queen's Department of Philosophy Colloquium and at the annual meetings of the Canadian Philosophical Association, the Western Canadian Philosophical Association, the North American Society for Social Philosophy, and the Society of Value Inquiry. The research for this paper was funded in part by the Ontario Graduate Scholarship program.

1 Sen develops his view in a number of works, see especially Inequality Reexamined, New York, Russell Sage, 1992; "Capability and Well-Being", in Martha Nussbaum and Amartya Sen, eds., The Quality of Life, Oxford, Oxford University Press, 1993, pp. 30-53; and Development as Freedom, New York, Anchor, 1999.

2 The capability approach has been taken up and developed by many othersnotably, Martha Nussbaum, Frontiers of Justice: Disability, Nationality, Species Membership, Cambridge, MA, Belknap, 2006. My discussion here is confined to Sen's articulation.

John Rawls, A Theory of Justice, Cambridge, MA, Belknap, 1971; John Rawls, Justice as Fairness: A Restatement, ed. Erin Kelly, Cambridge, MA, Belknap, 2001; Ronald Dworkin, Sovereign Virtue: The Theory and Practice of Equality, Cambridge, MA, Harvard University Press, 2000; G. A. Cohen, "On the Currency of Egalitarian Justice", Ethics, vol. 99, 1989, pp. 906-44; Richard Arneson, "Equality and Equal Opportunity for Welfare", Philosophical Studies, vol. 56, 1989, pp. 77-93. This debate was launched into prominence largely by Sen, "Equality of What?", in Sterling McMurrin, ed., The Tanner Lectures on Human Values, vol. i, Salt Lake City, University of Utah Press, 1980, pp 353-69.

4 This connection has also been noted by Thomas Hurka, "Capability, Functioning, and Perfectionism", Apeiron, vol. 35, 2002, pp. 137-62.

5 See, however, Sen, Inequality, p. 77, n. 12, and p. 85, n. 26.

6 I believe that my arguments can be extended to other defenses of liberal neutrality, but that is beyond the scope of this paper.

7 Martha Nussbaum defends her view as a form of Rawlsian political liberal- ism, see Nussbaum, Frontiers. I have doubts that this defence works, even if her version of the capability approach is attractive in other ways.

8 Rawls, Restatement, p. 40.

9 Will Kymlicka, Contemporary Political Philosophy: An Introduction, 2nd. ed., Oxford, Oxford University Press, 2002, p. 218.

10 Perfectionism can also be developed as a strictly ethical view. My focus here is perfectionism within political theory.

11 Although communitarians can accept that there are many different valuable ways of living (inter-community pluralism), to the extent that they are committed to fostering the bonds of community via a single shared way of life, their position is at odds with intra-community pluralism.

12 For instance, that the well-being of each citizen is of equal and objective importance. Cf. Dworkin, Sovereign Virtue, p. 5.

13 Steven Wall, "Perfectionism in Moral and Political Philosophy", in Edward N. Zalta, ed. The Stanford Encyclopedia of Philosophy, Spring 2007 ed., http://plato.stanford.edu/archives/spr2007/entries/perfectionism-moral/ (website consulted on July 6th, 2009).

14 See Kymlicka, Introduction, p. 190

15 Rawls, Theory, pp. 326-7.

16 Christine Sypnowich, "Equality: From Marxism to Liberalism (and Back Again)", Political Studies Review, vol. 1, 2003, pp. 333-43.

17 Comprehensive liberalism rejects only the second of these perfectionist claims, see Kymlicka, Introduction, ch. 6.

18 Amartya Sen, "Justice: Means versus Freedoms", Philosophy and Public Affairs, vol. 19, 1990, pp. 111-21.

19 John Rawls, "The Priority of Right and Ideas of the Good", Philosophy and Public Affairs, vol. 17, 1988, pp. 251-76.

20 Sen, "Means versus Freedoms", p. 118.

21 Ibid., p. 120, see also Sen, Inequality, p. 85.

22 It is not entirely clear whether Sen's understanding of 'neutrality' here is the justification-centered one that has become dominant. It may be that he has in mind 'consequential neutrality', which is not what the leading neutralists defend, see Will Kymlicka, "Liberal Individualism and Liberal Neutrality", Ethics, vol. 99, 1989, pp. 883-905.

23 Sen, "Means versus Freedoms", p. 120, n. 23, see also Inequality, p. 85, n. 26.

24 Sen, Inequality, p. 77, n. 12.

25 Sen, "Equality of What?", p. 216.

26 Sen, Inequality, pp. 36-8.

27 Rawls, Restatement, p. 149.

28 Sen, Inequality, p. 85

29 Rawls, Restatement, p. 8

30 Ibid., p. 170.

31 Amartya Sen, "Rights and Capabilities", in Ted Honderich, ed., Morality and Objectivity: A Tribute to J. L. Mackie, London, Routledge \& Kegan Paul, 1985, pp. $130-48$ at p. 142 .

32 Sen, Inequality, p. 28.

33 Ibid. 
34 One shortcoming of the capability approach is that Sen typically fails to distinguish between capability-reducing factors that are clearly morally arbitrary (e.g., chronic illness) and ones that are not (e.g., unhealthy choices), see Joshua Cohen, "Amartya Sen: Inequality Reexamined", Journal of Philosophy, vol. 92, 1995, pp. 275-88, and Norman Daniels, "Equality of What: Welfare, Resources, or Capabilities?", Philosophy and Phenomenological Research, vol. 50, 1990 pp. 273-96. This paper leaves this issue unresolved.

35 Sen, "Means versus Freedoms", p. 112.

36 There is a push in the literature on disability to describe disability in terms of a continuum and to emphasize how individuals inevitably occupy various locations along that continuum during their life span. The consequence is that disability becomes recognized as a normal part of the human condition. See Jerome E. Bickenbach, "Disability and Equality", Journal of Law and Equality, vol. 2, 2003, pp. 7-15.

37 Amartya Sen, Commodities and Capabilities, Amsterdam, North-Holland, 1985 , pp. $5-6$.

38 More specifically, capability is a measure of a person's feasible combinations of functionings. To illustrate, imagine two people (Peter and Roger) and three functionings (going to university, actively participating in the social life of the university, and graduating debt free). Suppose that an examination of functionings one at a time indicates both Peter and Roger are free to achieve each of the functionings, but if we look at which combinations of functionings they are free to achieve, we find out that Roger has the social and personal resources to achieve the combination of all three, whereas Peter is only free to achieve either 1 and 2 but not 3 , or 1 and 3 but not 2 - that is, if he goes to university, he has to choose between an active social life or graduating debt free. Therefore, we conclude that Roger has a higher level capability than Peter; he has a more valuable range of options; he has more positive freedom.

39 Amartya Sen, Rationality and Freedom, Cambridge, MA, Belknap, 2002, p. 13.

40 Sen, "Capability and Well-Being", p. 35.

41 James Griffin, Well-Being: Its Meaning, Measurement and Moral Importance, Oxford, Clarendon, 1986, p. 33.

42 Sen, Commodities, p. 35.

43 Position-dependence is the idea that people in different positions can have good reason to come up with different answers to the same evaluative exercise. Sen denies that the evaluation of well-being is person-relative, but he does think that is position-dependent. Sen writes, on page 35 of Commodities, that "an objectivist view would not necessarily rule out the possibility of interpersona variations of well-being rankings"-see also Development, ch. 15. The claim about incompleteness is the idea that when we look at a person's beliefs about the value of functionings, it may often be the case that not all pairs of functionings can be ranked by those beliefs, see Sen, Commodities, p. 16.

44 Sen, Commodities, p. 58
45 Sen writes on page 78 of Development that "in arriving at an "agreed" standard for social evaluation..., there has to be some kind of a reasoned "consensus" on weights, or at least on a range of weights."

46 I am inclined towards an intermediate position between the extreme version of the biomedical and social constructivist models of disability, but I do not fleshing out that position here. For an important contribution to that debate, see Jerome E. Bickenbach, Physical Disability and Social Policy, Toronto, University of Toronto Press, 1993.

47 Sen, Development, pp. 153-4

48 Sen, Rationality, p. 590: "[W]e can go even further and require reasoned scrutiny as a requirement of a preference ordering to have an important status in the evaluation of freedom. ... [A] valuational ranking that can survive reasoned scrutiny has a central role in the assessment of freedom. In the use of "preference" as the basis of evaluation of the opportunity aspect of freedom, a special place must be given to the valuational interpretation of preference, combined with the need for compatibility with reasoned scrutiny."

49 John Rawls, "The Basic Liberties and Their Priority", in Sterling McMurrin, ed., The Tanner Lectures on Human Values, vol. iii, Salt Lake City, University of Utah Press, 1982, pp. 1-89, at p. 25

50 Ibid., p. 28.

51 For a discussion of conceptions of autonomy in comprehensive and political liberalism, see Will Kymlicka, "Two Models of Pluralism and Tolerance", in David Heyd, ed., Toleration, Princeton, Princeton University Press, 1996, pp. 81-105; Liberalism, Community, and Culture, Oxford, Oxford University Press, 1989 , ch. 4.

52 Rawls, Restatement, p. 189.

53 Sen, Inequality, pp, 75-9. See also Amartya Sen, "What Do We Want from a Theory of Justice?", Journal of Philosophy, vol. 103, 2006, pp. 215-38.

54 On comprehensive liberalism, see Dworkin, Sovereign Virtue; Kymlicka, "Two Models"; Kymlicka, Introduction, ch. 6; Will Kymlicka, "Two Theories of Justice", Inquiry, vol. 33, 1990, pp. 99-119.

55 Sen, Development, p. 153.

56 John Rawls, "The Idea of Public Reason Revisited", University of Chicago Law Review, vol. 64, 1997, pp. 765-807. 